\title{
Developmental Changes in Constriction of the Ductus Arteriosus: Responses to Oxygen and Vasoactive Agents in the Isolated Ductus Arteriosus of the Fetal Lamb
}

\author{
Dorothy M. MaMurphy, Michael A. Heymann ${ }^{[25]}$, Abraham M. Rudolph, and \\ Kenneth L. Melmon \\ Departments of Pediatrics and Pharmacology and the Cardiovascular Research Institute, University of California, \\ San Francisco, California, USA
}

\section{Extract}

Development of the constrictor response of the ductus arteriosus to $\mathrm{O}_{2}$ and selected vasoactive drugs (acetylcholine and bradykinin) was studied in 20 fetal lambs weighing 680-4800 g (90- to 150-day gestation). The isolated ductus arteriosus was perfused in vitro with Tyrode's solution at constant flow, temperature $\left(38^{\circ}\right), \mathrm{pH}(7.3-7.4)$, and $\mathrm{P}_{\mathrm{CO}_{2}}(30-40 \mathrm{~mm} \mathrm{Hg})$, and the mean pressure difference across the ductus was measured. Ductal resistance was calculated at different levels of $\mathrm{P}_{\mathrm{O}_{2}}(10-700 \mathrm{~mm} \mathrm{Hg})$, raised stepwise to produce dose-response curves. Three young fetuses failed to respond initially to $\mathrm{O}_{2}$ and in the other 17 the initial response occurred at progressively lower $\mathrm{P}_{\mathrm{O}_{2}}$ levels with advancing gestation. The maximal degree of constriction developed showed a progressive increase with advancing gestational age.

At any given $\mathrm{P}_{\mathrm{O}_{2}}$, both acetylcholine and bradykinin produced a further increase in resistance when added to the perfusion solution, but this further increase was independent of age. The level of $\mathrm{P}_{\mathrm{O}_{2}}$ at which an initial response occurred was decreased after exposure to acetylcholine but not bradykinin.

\section{Speculation}

The ductus arteriosus of the fetal lamb constricts when exposed to oxygen. The initial level of $\mathrm{P}_{\mathrm{O}_{2}}$ at which this constriction occurs decreases, and the maximal degree of constriction increases, with advancing gestational age. The poor response to oxygen of the ductus arteriosus in the immature fetus may be the mechanism responsible for the high incidence of patent ductus arteriosus in premature infants. Constriction following oxygen may be augmented by the exposure to acetylcholine or bradykinin.

\section{Introduction}

In the normal transition from the fetal to the neonatal circulation, the ductus arteriosus is usually functionally closed within $10-15 \mathrm{hr}$ after birth [18]. It has been shown that $\mathrm{O}_{2}$ constricts the ductus arteriosus in both fetal and newborn animals of various species, as well as in the human infant $[1,5,9-11,13,15,16]$. In the premature human infant, ductal closure may be delayed even though oxygenation seems adequate [6]. 
The isolated perfused human fetal ductus arteriosus from the second trimester of pregnancy does not constrict with $\mathrm{O}_{2}$, indicating that this response develops later cluring fetal gestation [14]. There is little information regarding the patterns of response of the ductus arteriosus to changes in $\mathrm{Po}_{2}$, nor is there any evidence to show when the ductal constrictor response to $\mathrm{O}_{2}$ develops during gestation. The first part of the present study was designed to examine these relations.

Although increased oxygenation does constrict the ductus arteriosus, it is not clear that this is the only mechanism responsible for normal ductal closure. Several studies have shown that various vasoactive agents may cause ductal constriction. Kovalčik [13] showed that epinephrine, acetylcholine, and also bradykinin constricted the isolated lamb ductus arteriosus. Boréus and others found that acetylcholine and epinephrine produced similar constriction in the isolated human ductus arteriosus during both the early and late portions of the second trimester $[3,4,14]$. In addition, recent studies have demonstrated the interaction of $\mathrm{O}_{2}$ with bradykinin in relation to other adjustments from the fetal to neonatal circulation $[7,8]$. Therefore, in the second part of the study, we examined the interrelations between ductal response to $\mathrm{O}_{2}$ and to acetylcholine and bradykinin.

\section{Materials and Methods}

Studies were performed on 20 fetal lambs weighing $680-4800 \mathrm{~g}$, and between 90 - to 150 -day estimated gesta- tional age [2]. The ewe was anesthetized with low spinal analgesia $(20 \mathrm{mg}$ tetracaine $\mathrm{HCl})$. The fetus was then delivered by cesarean section and prevented from breathing by immediately placing a rubber glove over its head. It was killed by rapid exsanguination. Intact specimens of the ductus arteriosus and adjacent pulmonary arteries and aorta were dissected and immersed in Tyrode's solution $(\mathrm{NaCl}, 8 \mathrm{~g} ; \mathrm{KCl}, 0.2 \mathrm{~g}$; $\mathrm{CaCl}_{2}, 0.2 \mathrm{~g} ; \mathrm{MgCl}_{2} \cdot 6 \mathrm{H}_{2} \mathrm{O}, 0.1 \mathrm{~g} ; \mathrm{NaH}_{2} \mathrm{CO}_{3}, 1 \mathrm{~g}$; $\mathrm{NaH}_{2} \mathrm{PO}_{4} \cdot 1 \mathrm{H}_{2} \mathrm{O}, 0.05 \mathrm{~g}$; dextrose, $1 \mathrm{~g}$; and distilled water to $1000 \mathrm{ml}$ ). They were prepared for perfusion by cannulating the main pulmonary artery (inflow) and descending thoracic aorta (outflow) and securely suturing both right and left pulmonary arteries and the aorta just proximal to the ductus. This preparation was immersed in a constant temperature $\left(38^{\circ}\right) 50-\mathrm{ml}$ bath of the Tyrode's solution and perfused by the same solution in a closed system. A diagram of the perfusion apparatus is shown in Figure 1.

Common reservoirs supplied the system with the perfusion solution through which various gas mixtures of $\mathrm{O}_{2}, \mathrm{~N}_{2}$, and $5 \% \mathrm{CO}_{2}$ were bubbled to change the $\mathrm{PO}_{2}$ over a wide range $(10-700 \mathrm{~mm} \mathrm{Hg})$ at constant $\mathrm{PCO}_{2}(30-40 \mathrm{~mm} \mathrm{Hg})$. Gas sampling was done on the warmed perfusion solution $\left(38^{\circ}\right)$ just before entry into the ductus; $\mathrm{pH}, \mathrm{PO}_{2}$, and $\mathrm{PCO}_{2}$ were measured using Radiometer electrodes and blood gas meter. A peristaltic pump [19] provided a constant flow at $70-250 \mathrm{ml} /$ min, depending on fetal weight. The pump was calibrated after each study by timed collection of the perfusion solution. A differential strain gauge transducer

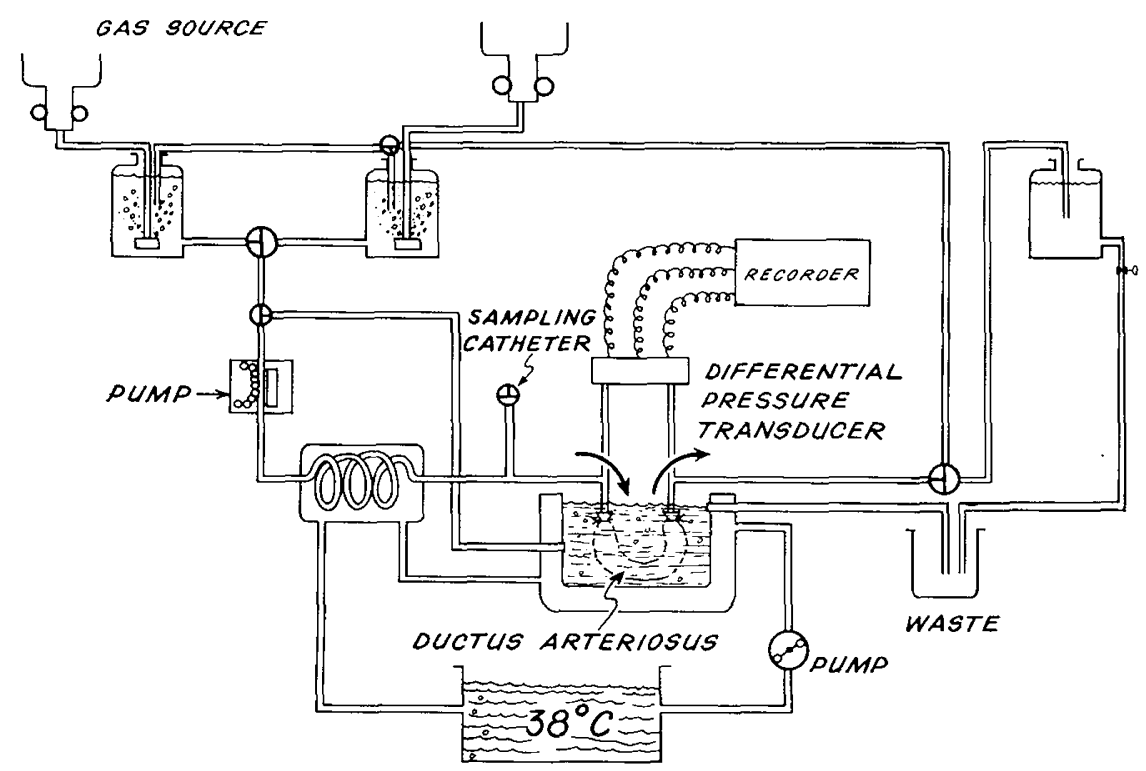

Fig. l. Diagrammatic representation of the perfusion system used. 
[20] continuously monitored proximal (pulmonary arterial), differential, ancl distal (aortic) mean pressures, which were recorded on a direct-writing polygraph [21]. Ductal resistance $\left(R_{D .1}\right)$ was calculated by dividing the pressure difference by flow. The ductus arteriosus was initially perfused with the Tyrode's solution at the lowest obtainable $\mathrm{PO}_{2}$, which was $9-15 \mathrm{~mm} \mathrm{Hg}$. The flow rate was adjusted to produce a mean perfu. sion pressure, proximal to the relaxed ductus arteriosus, of between 35 and $55 \mathrm{~mm} \mathrm{Hg}$, depending on fetal weight. The pressure for each perfusion was selected according to our own observations in undisturbed fetal lambs in utero at different gestational ages [17]. When the pressure was constant at the required preset level, with constant flow for about $30 \mathrm{~min}$, the preparation was considered to be in a base line state. If any change in the perfusion pressure occurred later at the original base line $\mathrm{PO}_{2}$ of about $10 \mathrm{~mm} \mathrm{Hg}$, the flow rate was adjusted to bring the pressure back to the original level.

Base line mean differential pressure across the ductus arteriosus was $1-3 \mathrm{~mm} \mathrm{Hg}$, which gave a calculated base line ductal resistance of $5-50 \mathrm{~mm} \mathrm{Hg} /$ liter/min, but was generally under $20 \mathrm{~mm} \mathrm{Hg} / \mathrm{liter} / \mathrm{min}$. First, an $\mathrm{O}_{2}$ dose-response curve was obtained by starting from this base line level at the lowest $\mathrm{Po}_{2}(10 \mathrm{~mm} \mathrm{Hg})$ and progressing stepwise up to the highest $\mathrm{PO}_{2}$ $(600-700 \mathrm{~mm} \mathrm{Hg})$. Initially, $15-20 \mathrm{~mm} \mathrm{Hg}$ increments were used until a $\mathrm{PO}_{2}$ of about $100 \mathrm{~mm} \mathrm{Hg}$ was reached. Thereafter the $\mathrm{PO}_{2}$ was raised in steps of 50-100 $\mathrm{mm} \mathrm{Hg}$. After any ductal contraction, the $\mathrm{PO}_{2}$ of the perfusion solution and the proximal pressure were returned to the base line level before proceeding with the next step.

The entire procedure was repeated by starting again at the lowest $\mathrm{PO}_{2}$ and increasing it stepwise to maximum. In addition, however, after a stabilization period following $\mathrm{O}_{2}$ exposure, during which either no constriction or a stable $\mathrm{O}_{2}$ response was elicited at each given $\mathrm{Po}_{2}$ level, a freshly prepared drug-either acetycholine or bradykinin, was added to produce a known concentration (generally $0.1,1.0$, or $10 \mu \mathrm{g} / \mathrm{ml}$ ) in the reservoir for continuous perfusion of the ductus. The drug was then completely washed out of the system from another reservoir and the ductus was relaxed to the base line before proceeding to the next higher step in $\mathrm{PO}_{2}$ level, with subsequent infusion of the same concentration of drug at the higher level of $\mathrm{Po}_{2}$. In this way, a second $\mathrm{O}_{2}$ dose-response curve was also obtained, but followed drug exposure. Continuous exposure to the drug was the only successful means of eliciting a ductal response. There was no ductal constriction following either rapid direct injection of a single bolus of drug into the system just before entry into the ductus or to the addition of the drug directly to the bath containing the ductus.

The response to $\mathrm{O}_{2}$ before and after drug exposure was evaluated and plotted against the increase in ductal resistance from the base line level. The additional response to the drug at each $\mathrm{Po}_{2}$ was also plotted.

Determinations were also made, both before and after drug exposure, of the $\mathrm{PO}_{2}$ level of the first constrictive response and of the maximal increase in ductal resistance from the base line level to the highest $\mathrm{PO}_{2}$.

Statistical analyses of these observations before and after exposure to either acetylcholine or bradykinin were made and, because of asymmetric distribution of the data, the Wilcoxson signed rank test was used.

\section{Results}

\section{Response to $\mathrm{O}_{2}$}

In three fetuses with gestational ages of 103, 120, and 125 days, no increase in pressure difference across the ductus arteriosus occurred when the perfusion solution $\mathrm{PO}_{2}$ was raised to $650-700 \mathrm{~mm} \mathrm{Hg}$.

In the other 17 fetuses, the first increase in pressure difference developed at perfusion solution $\mathrm{PO}_{2}$ levels between 67 and $700 \mathrm{~mm} \mathrm{Hg}$. The relation between gestational age and the level of $\mathrm{PO}_{2}$ at which the first increase in pressure difference developed is shown in Figure 2. The clecrease in the level of $\mathrm{Po}_{2}$ required to produce the initial constriction was linearly related to advancing gestational age $(P<0.01)$. In the two oldest fetuses of 150-day gestational age, obtained while the ewe was in labor, the constriction first occurred at 67 and $88 \mathrm{~mm} \mathrm{Hg}$.

In 5 of these 17 studies, the initial response in 3 was observed only when the $\mathrm{PO}_{2}$ was raised to $700 \mathrm{~mm} \mathrm{Hg}$ and, therefore, further stepwise increase was not possible. In two, the study was discontinued for technical reasons after the initial response was obtained. In the remaining 12 studies, the stepwise increase in $\mathrm{Po}_{2}$ was continued above the level at which the initial constriction was detected. This resulted in a progressive increase in the pressure difference across the ductus arteriosus. In 2 of these 12 studies, rupture of the ductus arteriosus occurred following intense constriction at $\mathrm{PO}_{2}$ levels of about $300 \mathrm{~mm} \mathrm{Hg}$.

The response of the ductus arteriosus to $\mathrm{O}_{2}$ was slow; the maximal pressure difference at any given 


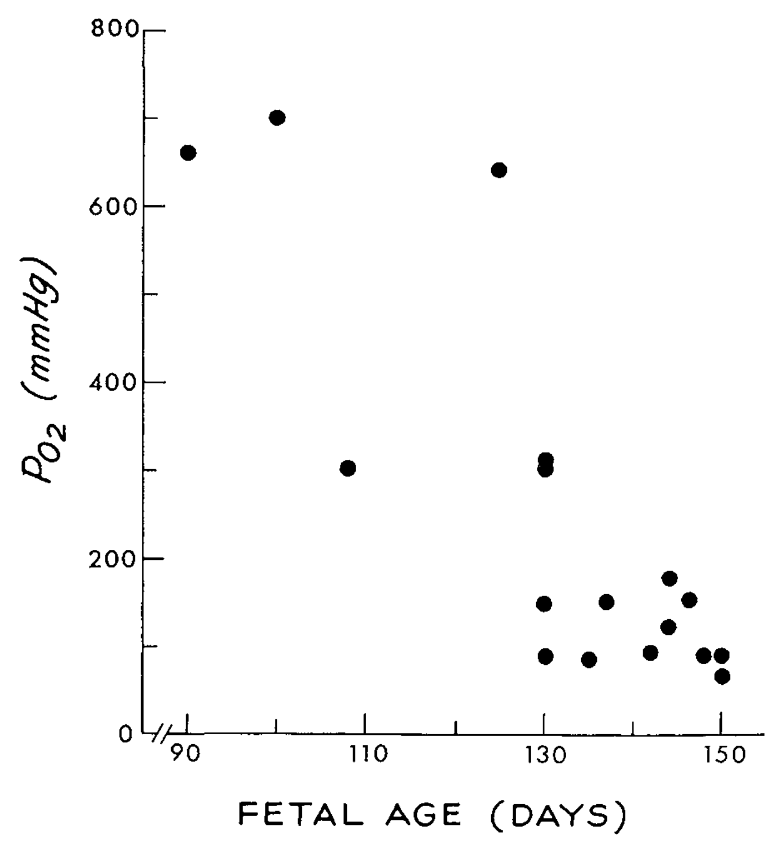

Fig. 2. $\mathrm{O}_{2}$ level of the initial ductal response to $\mathrm{O}_{2}$ alone before drug exposure in the isolated perfused ductus arteriosus in fetal lambs of increasing gestational age (90-150 days). Three of the younger fetuses below 125 days did not respond at all and are not shown; four others below 125 days responded only at very high $\mathrm{P}_{\mathrm{O}_{2}}$ levels. The older fetuses responded at much lower $\mathrm{P}_{\mathrm{O}_{2}}$ levels. level of $\mathrm{Po}_{2}$ required $5-10 \mathrm{~min}$ to develop. Actual recordings from one experiment are shown in Figure 3.

The degree of decrease in ductal diameter with constriction was assessed by calculating the $R_{D A}$ based on pressure-flow relations. The maximal increase in resistance which could be achieved with $\mathrm{O}_{2}$ was also related to gestational development, as shown in Figure 4. Thus, the amount of ductal contractile response was a function of both $\mathrm{O}_{2}$ concentration and age. As $\mathrm{Po}_{2}$ was raised, $R_{D A}$ increased and the degree of this response to $\mathrm{O}_{2}$ increased with age (Fig. 5).

\section{Response to Drugs}

The effects of acetylcholine or bradykinin on the ductus arteriosus at different levels of $\mathrm{Po}_{2}$ were examined in 15 of the fetuses. In most instances acetylcholine and bradykinin, when added to the perfusion solution, produced an additional increase in the pressure difference across the ductus arteriosus over and above that produced by $\mathrm{O}_{2}$ alone at any level of $\mathrm{PO}_{2}$ tested. In one fetus (103 days) neither drug produced constriction; two others (100 and 130 days) responded only to acetylcholine.

The effects of either drug and of $\mathrm{O}_{2}$ were additive. In eight studies the average maximal increase in $R_{\mathrm{DA}_{A}}$

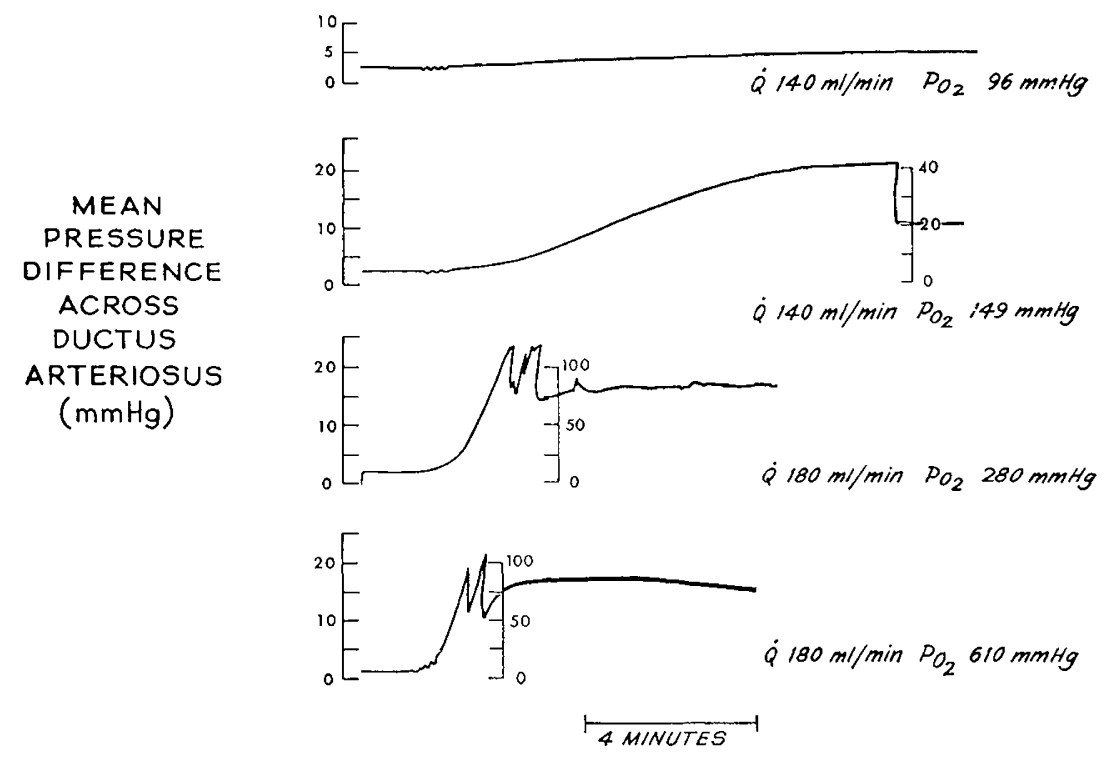

Fig. 3. Actual recordings of $\mathrm{O}_{2}$-induced contractions in an isolated perfused fetal lamb ductus arteriosus ( 142 days, $3.5 \mathrm{~kg}$ ). The mean pressure gradient across the ductus rose progressively from 5 to $90 \mathrm{~mm} \mathrm{Hg}$ as the $\mathrm{P}_{\mathrm{O}_{2}}$ level was increased from 96 to $610 \mathrm{~mm} \mathrm{Hg}$. There was no response from a $\mathrm{P}_{\mathrm{O}_{2}}$ of 10-96 mm Hg. In between contractions, the $\mathrm{P}_{\mathrm{O}_{2}}$ level was reduced to $10 \mathrm{~mm} \mathrm{Hg}$ so that pressure returned to the base line level of $2.0-2.5 \mathrm{~mm} \mathrm{Hg}$. Calculated ductal resistance increased from the base line level of 18 to $500 \mathrm{~mm} \mathrm{Hg}$, the maximum value at the highest $\mathrm{P}_{\mathrm{O}_{2}}$. The $\mathrm{pH}$ and $\mathrm{P}_{\mathrm{CO}_{2}}$ were constant at 7.38 and $40 \mathrm{~mm} \mathrm{Hg}$, respectively. In panels 2,3 , and 4, the sensitivity of the recorder was changed when the pressure difference exceeded the original scale. 


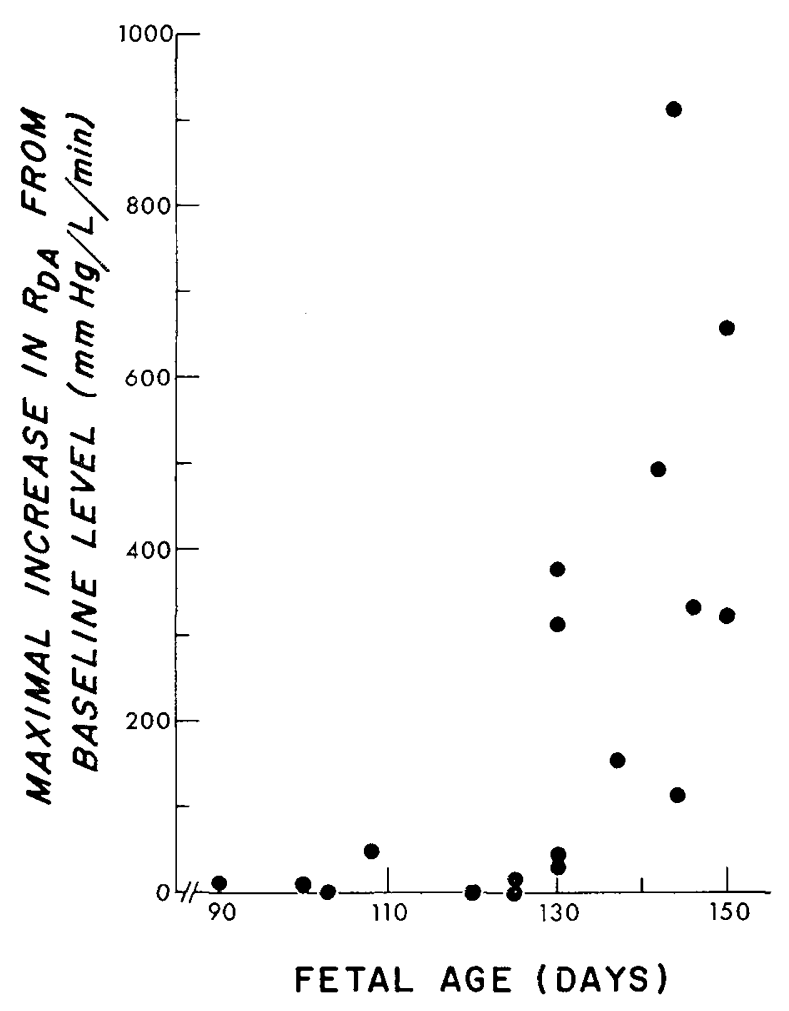

Fig. 4. Maximum ductal response to $\mathrm{P}_{0.2}$ levels over $600 \mathrm{~mm} \mathrm{Hg}$ before drug exposure in the isolated perfused ductus arteriosus in fetal lambs of increasing gestational age (90-150 days). The response is age-related. Three of the younger fetuses $(<125$ days) did not respond at all. In the four other fetuses $<125$ days the increase in maximum $R_{D A}$ from base line relaxation level was considerably less than in fetuses over 130 days old. The zero $R_{D_{A}}$ is the base line resistance, which varied from 7 to $40 \mathrm{~mm} \mathrm{Hg}$ / liter/min.

from base line with $\mathrm{O}_{2}$ alone was $103 \mathrm{~mm} \mathrm{Hg} /$ liter/ min. After the addition of acetylcholine, at the same $\mathrm{PO}_{2}$ in each instance, the average rose to $290 \mathrm{~mm} \mathrm{Hg} /$ liter $/$ min $(P<0.01)$. In seven similar studies with bradykinin, the average rose from 237 to $331 \mathrm{~mm} \mathrm{Hg} /$ liter $/ \min (P<0.05)$. The ability to respond when exposed to each drug was noted in ductuses from all gestational ages studied. The additional response to bradykinin was noted only when a response to $\mathrm{O}_{2}$ alone had already been produced. However, addition of acetylcholine produced a constriction at a $\mathrm{Po}_{2}$ level below that at which constriction resulted from $\mathrm{O}_{2}$ alone. The average $\mathrm{Po}_{2}$ at which constriction was first detected with $\mathrm{O}_{2}$ alone was $424 \mathrm{~mm} \mathrm{Hg}$; following addition of acetylcholine, this fell to $204 \mathrm{~mm} \mathrm{Hg}(P<$ 0.05). An example of the effect of acetylcholine is shown in Figure 6.

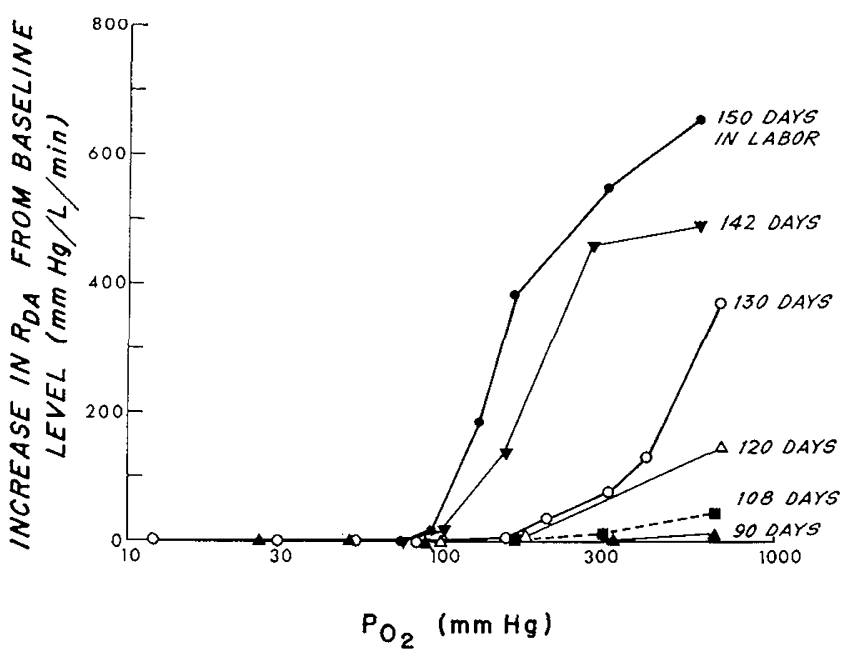

Fig. 5. $\mathrm{O}_{2}$ dose-response curves from isolated perfused fetal lamb ductus arteriosus of varying gestational ages (90-150 days). The most mature fetus (150 days) was obtained during labor. $R_{D A}$ increased with progressively higher $\mathrm{P}_{\mathrm{O}_{2}}$ levels. The earliest responses to $\mathrm{O}_{2}$ and the greatest degrees of response were seen in the oldest fetuses. The youngest fetuses responded minimally at the highest $\mathrm{P}_{\mathrm{O}_{2}}$ level. The zero $R_{D_{A}}$ is the resistance at base line level, which varied from 8 to $40 \mathrm{~mm} \mathrm{Hg} /$ litcr/min.

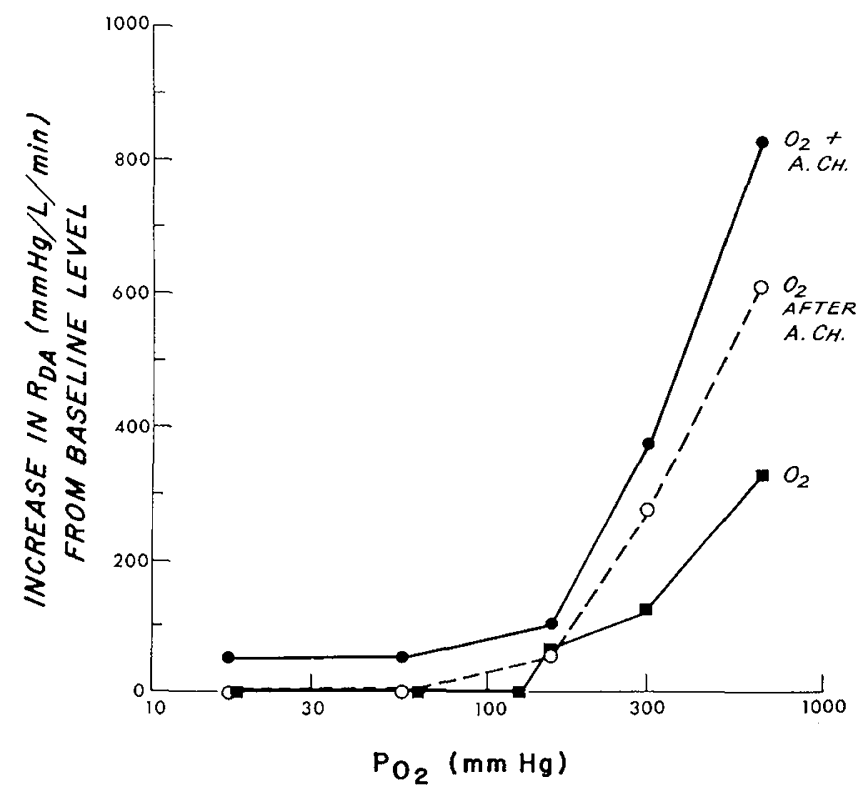

Fig. 6. $\mathrm{O}_{2}$ response curves for the first $\mathrm{O}_{2}$ exposure before drugs $(\square)$, the second $\mathrm{O}_{2}$ exposure after previous drug contact $(\mathrm{O})$, and for acetylcholine $10 \mu \mathrm{g} / \mathrm{ml}(\bullet)$ following a stable response of the second $\mathrm{O}_{2}$ exposure in an isolated perfused fetal lamb ductus arteriosus (146 days, $3.6 \mathrm{~kg}$ ). The first and second $\mathrm{O}_{2}$ responses occur initially at the same $\mathrm{P}_{\mathrm{O}_{2}}(155 \mathrm{~mm} \mathrm{Hg})$, but the response of the second $\mathrm{O}_{2}$ exposure is higher. The initial response to acetylcholine occurs at a much lower $\mathrm{P}_{\mathrm{O}_{2}}(17 \mathrm{~mm} \mathrm{Hg})$ and is greater than the second $\mathrm{O}_{2}$ response. Zero base line level is 20 $\mathrm{mm} \mathrm{Hg} / \mathrm{liter} / \mathrm{min}$. 
Response to $\mathrm{O}_{2}$ Following Exposure to Acetylcholine and Bradykinin

In 13 of the 20 fetuses, responses to increasing $\mathrm{O}_{2}$ levels were determined a second time following drug exposure. In three $(90,100$, and 103 days), there was no change in initial response; two (120 and 125 days) that had not responded previously to $\mathrm{O}_{2}$ alone now responded at $\mathrm{Po}_{2}$ levels of 171 and $630 \mathrm{~mm} \mathrm{Hg}$, respectively. Two other young fetuses (108 and 125 days) had previously responded to $\mathrm{O}_{2}(300$ and $640 \mathrm{~mm} \mathrm{Hg}$ ), but on second exposure the $\mathrm{PO}_{2}$ level of the initial response was considerably lower (161 and $290 \mathrm{~mm} \mathrm{Hg}$, respectively). In the six older fetuses over 130 days, the $\mathrm{Po}_{2}$ level of the initial response to $\mathrm{O}_{2}$ following drug exposure (mean, $149 \mathrm{~mm} \mathrm{Hg}$ ) was unchanged from before (mean, $145 \mathrm{~mm} \mathrm{Hg}$ ). Thus, reduction of the threshold $\mathrm{PO}_{2}$ level for initial ductal constriction to $\mathrm{O}_{2}$ after drug exposure occurred only in the group below 130 days.

The maximal degree of constriction that could be obtained with high $\mathrm{Po}_{2}$ levels following drug exposure was studied in only six fetuses. The average maximal increase in $R_{D A}$ for $\mathrm{O}_{2}$ exposure prior to drug administration was $208 \mathrm{~mm} \mathrm{Hg} / \mathrm{liter} / \mathrm{min}$; this rose to $289 \mathrm{~mm}$ $\mathrm{Hg} /$ liter/min on the second exposure to $\mathrm{O}_{2}$ after drug responses had been measured. Although this showed a trend, it was not statistically significant.

\section{Discussion}

Closure of the ductus arteriosus after birth is frequently delayed in premature human infants [6]. Recently, a review of 111 inborn infants weighing under $1750 \mathrm{~g}$ revealed that $15.3 \%$ had variable degrees of patency of the ductus arteriosus beyond the 1st week of life, confirmed by cardiac catheterization in many instances [12]. The reason for this high incidence has not been evident, but several possibilities are suggested.

A level of $\mathrm{PO}_{2}$ sufficient to produce ductal constriction may not be achieved if there is inadequate ventilation. Other possibilities include an inadequate amount of ductal smooth muscle to effect constriction, absence of the receptor sites responsive to $\mathrm{O}_{2}$, or lack of development of a chemical mediator which produces the constrictor response to increased $\mathrm{PO}_{2}$.

Our present studies provide evidence that, in the fetal lamb, the response of the ductus arteriosus to $\mathrm{O}_{2}$ is related to gestational age. No constriction was noted in ductuses derived from three young lambs despite a rise in the perfusion solution $\mathrm{PO}_{2}$ to $650 \mathrm{~mm} \mathrm{Hg}$ or higher. In those which responded, there was, with advancing gestation, a decrease in the level of $\mathrm{PO}_{2}$ which produced the initial constriction, ranging from $300-700 \mathrm{~mm} \mathrm{Hg}$ in the 90 - to 110-day fetuses to about $70-90 \mathrm{~mm} \mathrm{Hg}$ in the term fetuses. Although responses of the isolated perfused ductus arteriosus cannot be compared with those in vivo, this latter $\mathrm{Po}_{2}$ is achieved soon after birth in most premature as well as mature infants. Thus, the high incidence of persistent patency of the ductus arteriosus in premature human infants could be related to a lack of responsiveness of the ductus arteriosus to $\mathrm{O}_{2}$ at an early gestational age.

We found, too, that the maximal degree of constriction attainable by increasing $\mathrm{PO}_{2}$ was also related to gestational age. Little or no constriction was obtained in 90- to 125-day fetuses, whereas after 130 days there was a sharp increase in the amount of constriction. Assali et al. [1] have shown that in the lamb near term there was a linear relation between ductal flow and $\mathrm{PO}_{2}$ levels of $50-700 \mathrm{~mm} \mathrm{Hg}$. However, we found a curvilinear type of response, with complete constriction and rupture of the ductus, in two instances at a $\mathrm{PO}_{2}$ level of $300 \mathrm{~mm} \mathrm{Hg}$.

It is important to realize that in the type of preparation used in this study, the ductus might have been held open by the high perfusion pressures which developed when constriction occurred. Since the initial pressures and flows were similar to those estimated to be present in the living fetus in utero, and since flow was maintained constant, increasing ductal constriction resulted in higher perfusion pressures. It is quite possible that complete closure might have been accomplished if intraluminal pressures were not as high. In the younger fetuses, since high intraluminal pressure did not develop, this was not an important consideration in the failure to demonstrate effective constriction in response to $\mathrm{O}_{2}$.

The technique may be criticized for its relative insensitivity to demonstrate small changes in muscle length. On the basis of the Poiseuille equation, the pressure difference measured across the ductus with constant laminar flow is inversely related to the fourth power of the radius. Thus, the same change in muscle length would produce a greater change in ductal resistance and pressure differential in a ductus with a smaller resting radius than with a larger one. Therefore, the method that we used would be more sensitive for showing constriction in the younger fetus with a ductus arteriosus of small diameter than in the older fetus. The changes in ductal resistance which we observed in the larger ductuses at later gestation, therefore, indicate considerable degrees of muscular response to $\mathrm{O}_{2}$ and reduction in lumen diameter.

The direct measurement of changes in muscle ten. 
sion is more sensitive than the method that we used and, in preliminary studies with ductal strips or rings suspended in a bath, small degrees of response to $\mathrm{O}_{2}$ have been observed at gestational ages below 90-100 days.

Acetylcholine and bradykinin each produced an increase in the degree of constriction of the ductus occurring at different $\mathrm{PO}_{2}$ levels. We did not examine the effect of acetylcholine and bradykinin together, so it is not known whether they share a common pathway in their action. However, an important difference in the effect of acetylcholine and bradykinin was observed. The initial response to bradykinin occurred at the same $\mathrm{PO}_{2}$ level at which any response to $\mathrm{O}_{2}$ was first noted; with acetylcholine, the constriction was observed at a lower level of $\mathrm{PO}_{2}$ than that produced with $\mathrm{O}_{2}$ alone. This difference in the effect of the two drugs is unexplained, although the mechanism of action of acetylcholine may be independent of $\mathrm{O}_{2}$, but that for bradykinin may be operative only in the presence of high concentrations of $\mathrm{O}_{2}$.

Following exposure to both bradykinin and acetylcholine, the ductus arteriosus of the younger fetuses responded initially to a lower $\mathrm{PO}_{2}$ than before exposure to the drugs. This effect persisted for at least several hours after the drug had been completely washed out of the bath. It could indicate some long term attachment of the drug in amounts which were ineffective alone in producing constriction, or there could be some alterations in the receptors responding to $\mathrm{O}_{2}$.

These studies suggest that delayed closure of the ductus arteriosus in premature infants is related to an ineffective constriction of their ductuses in response to increases of $\mathrm{PO}_{2}$. It has not, however, resolved the question as to whether this is due to an inadequate muscular growth or to lack of development of adequate receptor function. The fact that acetylcholine lowers the $\mathrm{PO}_{2}$ at which ductus arteriosus constriction occurs in the isolated premature lamb ductus suggests the possibility that it could be useful in stimulating such constriction in the premature human infant when $\mathrm{O}_{2}$ alone is ineffective.

\section{Summary}

Constriction of the isolated perfused ductus arteriosus in fetal lambs is produced by increasing the $\mathrm{PO}_{2}$ of the perfusing solution. The $\mathrm{PO}_{2}$ level at which constriction is first produced is age-dependent, the ductus from the older fetuses responding at a significantly lower $\mathrm{PO}_{2}$ level than that from the younger fetuses. Likewise, the maximal constriction developed at high $\mathrm{PO}_{2}(600 \mathrm{~mm}$ $\mathrm{Hg}$ ) is age-dependent, with the ductus arteriosus from older fetuses constricting more than those from younger fetuses.

Both acetylcholine and bradykinin were able to increase the amount of constriction of the ductus arteriosus at any level of $\mathrm{PO}_{2}$ irrespective of the age of the fetus.

\section{References and Notes}

1. Assali, N. S., Morris, J. A., Smith, R. W., and Manson, W. A.: Studics on ductus arteriosus circulation. Circulation Res., 13: 478 (1963).

2. BARCRoFT, J.: Researches on Prennatal Life. (Charles C Thomas, Springfield, IIl., 1947).

3. Borḱus, L. O.: Pharmacology of the human fetus: doseeffect relationships for acetylcholine during ontogenesis. Biol. Neonatorum, 11: 328 (1967).

4. Boréus, L. O., Malmfors, T., MCMurphy, D. M., and Olson, L.: Demonstration of adrenergic receptor function and innervation in the ductus arteriosus of the human fetus. Acta Physiol. Scand., 77: 316 (1969).

5. Born, G. V. R., Dawes, G. S., Mott, J. C., And Rennick, B. R.: The constriction of the ductus arteriosus caused by oxygen and by asphyxia in newborn lambs. J. Physiol. (London), 132: 304 (1956).

6. Danilowicz, D., Rudolph, A. M., and Hoffman, J. I. E.: Delayed closure of the ductus arteriosus in premature infants. Pediatrics, 37: 74 (1966).

7. Eltherington, L. G., Stoff, J., Hughes, T., and Melmon, K. L.: Constriction of human umbilical arteries. Interaction between oxygen and bradykinin. Circulation Res., 22: 747 (1968).

8. Heymann, M. A., Rudolph, A. M., Nies, A. S., ANd Melmon, K. L.: Bradykinin production associated with oxygenation of the fctal lamb. Circulation Res., 25: 521 (1969).

9. HörNblaD, P. Y.: Experimental studies on closure of the ductus arteriosus utilizing whole-body freezing. Acta Paediat. Scand., Suppl. 190: 1 (1969).

10. Hörnblad, P. Y.: Effect of oxygen and umbilical cord clamping on closure of the ductus arteriosus in the guinea-pig and the rat. Studies on closure of the ductus arteriosus. VI. Acta Physiol. Scand., 76: 58 (1969).

11. KenNedy, J. A., AND Clark, S. L.: Observations on the physiological reactions of the ductus artcriosus. Amer. J. Physiol., 136: 140 (1942).

12. Kitterman, J. A., Gregory, G. A., Edmunds, L. H., HeyMaNN, M. A., and Rudolph, A. M.: Unpublished obscrvations.

13. Kovalčrk, V.: The response of the isolated ductus arteriosus to oxygen and anoxia. J. Physiol. (London), 169: 185 (1963).

14. McMurphy, D. M., And BorÉus, L. O.: Studies on the pharmacology of the perfused human fetal ductus arteriosus. Amer. J. Obstet. Gynecol., 109: 937 (1971).

15. Moss, A. J., Emmanoullides, G. C., Adams, F. H., and Chuang, $\mathrm{K}$.: Response of ductus arteriosus and pulmonary and systemic arterial pressure to changes in oxygen environment in newborn infants. Pediatrics, 33: 937 (1964).

16. Reis, R. L., And Anderson, R. P.: Constriction of the ductus arteriosus. Experimental observations in the newborn lamb. J. Surg. Res., 4: 356 (1964). 
I7. Rudolph, A. M., And Heymann, M. A.: Unpublished observations.

18. Rudolph, A. M., Drorbaugh, J. E., Auld, P. A. M., Rudolph, A. J., Nadas, A. S., Smith, C. A., And Hubbell, J. P.: Studies on the circulation in the neonatal period. The circulation in the respiratory distress syndrome. Pediatrics, 27: 551 (1961).

19. Model 1215, Harvard Apparatus Company, Millis, Mass.

20. $\mathrm{P} 23 \mathrm{H}$, Statham Instruments, Inc., Oxnard, Calif.

21. Model 5A, Grass Instrument Company, Quincy, Mass.

22. Dr. McMurphy's present address is: Fagottvägen 6, S-43500 Mölnlycke, Sweden.
23. Dr. Heymann was the recipient of Research Career Development Award no. HD 35398 from the National Institute of Child Health and Human Development.

24. Supported by Grants nos. HE-06285 and HE-09964 from the National Heart and Lung Institute, and by Grant no. GM01791 from the National Institute of General Medical Sciences.

25. Requests for reprints should be addressed to: MichaEl A. Heymann, M.B., B.Ch., Cardiovascular Research Institute, University of California, San Francisco, California 94122 (USA).

26. Accepted for publication September 23, 1971. 